\title{
A New Measure of the Quality of Tourism Product
}

\author{
Maria do Rosário Campos Mira \\ Polytechnic Institute of Coimbra, Higher School of Education \\ Andreia Filipa Antunes Moura \\ Polytechnic Institute of Coimbra, Higher School of Education \\ Lisete dos Santos Mónico \\ University of Coimbra, Faculty of Psychology and Educational Sciences
}

Received July 7 2018; received in revised form 16 November 2015; accepted 10 December 2018

\begin{abstract}
Tourism product competitiveness depends on innovation and quality levels and on its capacity to reflect the destinations' identity. For these reasons and inspired by the EC and UNWTO recommendations we developed a tourism quality scale, adapted to the Portuguese reality, which is supported by 5 subscales. This paper focuses on the validation of the tourism product subscale, which was tested among local public stakeholders, specifically Portuguese municipalities. Exploratory and confirmatory factor analyses were performed, and three factors supported quality measurement regarding the tourism product: (1) services; (2) resources and attractions; and (3) accessibilities and infrastructures. Results demonstrate there are theoretical and practical implications and the conclusions provide useful insights for future research.
\end{abstract}

Key Words: Quality, Product, Scale, Tourism

JEL Classification: L15, C3

\section{Introduction}

This article is the last of a series of five. The series aims to validate the psychometric properties of a measuring instrument, adapted to the Portuguese reality, which evaluates the perception of local public decision-makers about the quality of tourism. 125 Portuguese counties participated, totalling 134 respondents. The questionnaire built for this study ('Quality of tourist destinations' - QTD) is organized into subscales or quality dimensions, namely: economic, development, human 
resources, marketing, and product. As a whole, this project aims to endow the Portuguese Destination Management Organization (DMO) of instruments that are adapted to the local reality and of easy application, collection, and data processing. This said, the main intention is to assure DMOs possess tools that allow them to easily monitor their counties' touristy activity. Instruments with these characteristics are scarce and none-existing adapted to the Portuguese reality at the local level. The different subscales of QD-TUR can be applied together or separately accordingly to the objectives and necessities of each organization. For this reason, each of these subscales were treated as an autonomous instrument.

This works' objective is to present the results related to the validation of the 'product' subscale. It is shown that 'services', 'resources and attraction', and 'accessibilities and structures' are the dimensions that respondents take into consideration in regard to the conception of competitive and differentiated tourism products.

In Portugal, creating conditions that make tourism competitive at a local level come mostly from the initiative of local public power such as Town Halls. Therefore, the Town Halls become the DMO with responsible for the promoting of tourism destinations identity at the Town level. They also play a major role in: (Stylidis, Sit, \& Biran, 2016): (i) planning of local tourism; (ii) supporting business initiative; (iii) promotion of the tourism destinations and fomenting networking; (iv) coordination between public and private sectors; (v) attracting funding, business, target markets, and specialized knowledge in the region under their supervision. For these reasons, it is important to understand which factors to consider when developing tourism products are and how these will be reflected in the quality of the offer from the perspective of someone who has a broad vision of the local level destinations.

\section{Literature Review}

Undoubtedly, the tourist profile is changing. Tourists are increasingly demanding and selective and are becoming progressively captivated by endogenous and authentic attractions that portray the uniqueness of destinations (Badulescu, Hoffman, Badulescu \& Simut, 2016). The new context of international tourism stresses that tourism products evolve towards the tourism experience, which arises from the 
activation of cultural and natural resources of a certain region (Bernabé \& Hernández, 2016).

For these authors, the tourism experience relies on stakeholders' partnerships, which, in turn, support political strategies that promote the incorporation of all dimensions of the cultural and natural patrimony, in order to transform local wealth into competitive tourism resources. Within this context, emphasis is given to tourism products and services management. in that placing tourists in the centre of the initial development stage of products and tourism markets in the final stage of this process, aiming to increase exportation earnings (Blasco, Guia \& Prats, 2014; Bohlin, Brandt \& Elbe, 2016). To Booyens and Rogerson (2016), it is also necessary to combine local and non-local, tangible and intangible resources, such as: knowledge (tacit, technical and scientific), technology, professional experience and other personal and professional skills, fundamental for the innovation of products and services. Offering a tourism experience relies on a type of creative tourism that sets innovation at the centre of product development, thus responding to changing demand motivations.

Creative tourism stimulates variety and product differentiation by reinventing them and adding them value (Bohlin et al., 2016; Sanz-Ibáñez \& Clavé, 2016). Products and services competitiveness depend on their innovation and quality levels and on their capacity to reflect the destinations' identity. Developing tourism products and services under this perspective ensures destination attractiveness. In new economies driven by creativity, knowledge and technological development, innovation is considered to be the success key to achieve competitiveness (Booyens, 2016; Sarasa, 2015; Királ'ová, 2016).

Innovative tourism products are often associated with authenticity. In this spectrum, innovation means circumscribing the focus on what is unique and authentic in the local culture, as well as on the means to present these experiences to visitors (Bohlin et al., 2016; Sanz-Ibáñez \& Clavé, 2016). Creating, better said co-creating, promotes knowledge transfer between local stakeholders and communities, thus increasing mutual skills to deal with competition, access to new niche markets and therefore leading to tourist's loyalty (Booyens \& Rogerson, 2015).

In this sense, it's important to create a consistent tourism supply based on a solid product strategy that highlights the differentiating characteristics of products as well as other conditions for attractiveness (Badulescu et al., 2016; Booyens \& Rogerson, 2015, 2016; De Noni, Orsi \& Zanderighi, 2014; Rovira, 2016). In synthesis, these are the 
premises that promote meaningful tourism experiences in a given region. Under these conditions, territories tend to be attractive for tourists and for highly qualified workers. It's this dynamic and ability to attract that leads to a higher index of product competitiveness. But there's no competitiveness without quality, meaning that tourists may feel attracted and motivated to go to certain destinations, but territories' ability to consolidate a rentable search volume, from an economic point of view, also depends on the quality of products and services provided to the costumer.

In this context, there are some topics to consider, namely:

a) the sustainability of the destinations' brand, in the long term, depends on the quality of client service, products, suppliers, and productive capacity (Nilsson, Eskilsson \& Ek, 2010; Királ'ová, 2015);

b) the basic element to transform a given space into a tourism destination is a quality environment (Sarasa, 2015);

c) there are no quality tourism destinations without high qualifications in the hospitality business (Soares, Baidal \& Gândar, 2015);

d) the product's quality is usually evaluated by its value for money perception and by its level of innovation (Weidenfeld, 2013);

e) the higher quality of social and communicational skills the tourist has, greater the need for the destination to exhibit high quality patterns (Volgger \& Pechlaner, 2015).

In summary, the consulted authors defend that the tourism product must have quality to be internationally attractive and competitive. For such it needs: (i) cultural and natural diversity; (ii) external promotion and internal cohesion; (ii) accessible transport network; (iv) being inserted in a network that assures political support as well as the fundamental natural resources for its sustainability (Bernabé \& Hernández, 2016; Bohlin et al., 2016; Ferdinand \& Williams, 2013; Getz \& Page, 2016; Rovira, 2016; Timothy, Saarinen \& Viken, 2016; Wieckowski \& Cerić, 2013).

\section{Methodology}

\subsection{The sample}


The proposed "Tourism product subscale" was tested among one hundred and twenty five municipalities, corresponding to $40.6 \%$ of the total Portuguese municipalities $(\mathrm{N}=308)$. From the participating municipalities, answered the survey 134 participants (see Table 1). Most of the respondents were aged from 35 to 49 years old $(65.7 \%)$ and there were more female $(57.5 \%)$ than male $(42.5 \%)$. The majority occupies the position of Senior Technician (59.7\%), above $80 \%$ work in the tourism department of municipalities $(81.3 \%)$ and have been working at the institution for more than 10 years (56.7\%). Most of them hold a tenure position (63.4\%) and have higher education qualifications at the undergraduate level (50.0\%), followed by a master's $(20.1 \%)$ or a postgraduate degree $(21.6 \%)$ (Table 1$)$.

Table 1

Characteristic of participants from the $\mathbf{1 2 5}$ Portuguese municipalities [N = 134 participants]

\begin{tabular}{|c|c|c|}
\hline Sample & $n$ & $\%$ \\
\hline \multicolumn{3}{|l|}{ Sex: } \\
\hline Male & 57 & 42.5 \\
\hline Female & 77 & 57.5 \\
\hline \multicolumn{3}{|l|}{ Age: } \\
\hline Between 18 and 24 years & 1 & 0.7 \\
\hline Between 25 and 34 years & 24 & 17.9 \\
\hline Between 35 and 49 years & 88 & 65.7 \\
\hline Between 50 and 64 years & 20 & 14.9 \\
\hline Over 64 years & 1 & 0.7 \\
\hline \multicolumn{3}{|l|}{ Working time in the Municipality: } \\
\hline Up to 1 year & 4 & 3.0 \\
\hline From 1 to 5 years & 22 & 16.4 \\
\hline From 5 to 10 years & 32 & 23.9 \\
\hline More than 10 years & 76 & 56.7 \\
\hline \multicolumn{3}{|l|}{ Positions in the Municipality: } \\
\hline Technical position & 109 & 68.6 \\
\hline Political position & 25 & 15.7 \\
\hline Mayor & 3 & 1.89 \\
\hline Alderman & 9 & 5.66 \\
\hline Vice President & 4 & 2.52 \\
\hline Other & 9 & 5.66 \\
\hline \multicolumn{3}{|l|}{ Hiring regime of workers in the Municipality: } \\
\hline Term employment contract & 4 & 0.8 \\
\hline Permanent employment contract & 85 & 10.5 \\
\hline Individual work contract & 7 & 0.8 \\
\hline Consultant & 6 & 4.5 \\
\hline Other & 7 & 5.2 \\
\hline Missing-values & 25 & 18.7 \\
\hline \multicolumn{3}{|l|}{ Professional category: } \\
\hline Director of services and equivalent positions & 1 & 0.7 \\
\hline Head of Division & 14 & 10.4 \\
\hline Sub director, Director General and equivalent positions & 1 & 0.7 \\
\hline Senior Technician & 80 & 59.7 \\
\hline Other & 13 & 9.7 \\
\hline Missing-values & 25 & 18.7 \\
\hline \multicolumn{3}{|l|}{ Qualifications: } \\
\hline Basic education (9th year) & 1 & 0.8 \\
\hline Secondary Education (12th year) & 5 & 3.7 \\
\hline Bachelor's degree & 4 & 3.0 \\
\hline Graduation & 67 & 50.0 \\
\hline Postgraduate studies & 29 & 21.6 \\
\hline Master & 27 & 20.2 \\
\hline $\mathrm{PhD}$ & 1 & 0.8 \\
\hline
\end{tabular}


Source: Own source based on the SPSS software output (version 22.0)

Local public stakeholders were considered as the target study population; since literature suggests that tourism competitiveness involves the active participation of stakeholders in the definition of policies, planning and strategic orientation for destinations. For this reason, it is emphasised the importance of assessing the quality of destinations, through indicators that reflect the concerns of DMO's at the local level. Portuguese municipalities have many of these responsibilities in the territories they manage, including in the tourism sector. Knowing their perception about indicators that assess of the tourism product was the foundation for building this questionnaire.

\subsection{Questionnaire construction}

The entitled "Tourism product subscale" was designed considering the European Commission (Comissão Europeia, 2000, 2003, 2013, 2016) and the United Nations World Tourism Organization (UNWTO, 2007, 2010, 2012) recommendations. These entities defend that the tourism products should guarantee some conditions, namely: (i) attraction; (ii) access; (iii) activity; (iv) services; (v) qualified personnel; and (vi) promotion. The questions related to the qualification of human resources and promotion was previously treated in the subscales 'human resources in tourism' and 'destination marketing strategy' (Mira, Mónico \& Moura, 2017). The subscale presented in this article highlights the attraction, access and services dimensions. The activity dimension, when related to the tourism experience, becomes part of the services component.

Moreover, the presented questionnaire was also supported by the previous research on the analysis of competitiveness indicators of destinations adapted to the Portuguese reality (Mira, Breda, Moura \& Cabral, 2017; Mira, Mónico, Moura, \& Breda, 2017; Mira, Mónico \& Moura, 2017; Mira, Moura \& Breda, 2016).

The results of these different studies and publications allowed the definitions of the items presented in this questionnaire (Table 2).

The main procedures in the construction of a measurement scale were followed, including the design and execution of different studies for development and improvement of the questionnaire, which led to the creation of the final version of the scale (Nunnally \& Bernstein, 1994; Netemeyer, Bearden \& Sharma, 2003). Likert's recommendations (1932) in the construction of scales (see Lima, 2000) were also 
followed. Thus, based on the literature review, a set of items that expressed opinions about the product dimension of quality in tourism were created, having been selected 25 that showed a favourable or unfavourable position (see Table 2). Then a sample described on Table 1 were asked to evaluate each of them using a 5-point Likert scale (from $1=$ strongly disagree to $5=$ strongly agree). The questionnaire also included a set of questions to determine the sociodemographic profile of the respondents.

Table 2

Tourism product subscale

\section{Instructions}

This questionnaire intends to collect data on the quality of tourism destinations. Your participation is voluntary and, in case you accept to participate, we kindly ask you to answer all the questions. If you leave some blank, it compromises the inclusion of your questionnaire in the study. The questionnaire is confidential, and your answers will be anonymous. There are no right or wrong answers. It is expected sincerity in the responses, not needing to spend time reflecting to give your answer.

Thank you very much for your participation!

The following list contains statements regarding the product dimension of quality in tourism. Please select your answer according to the scale below:

1.1 According to my municipality, I consider that:

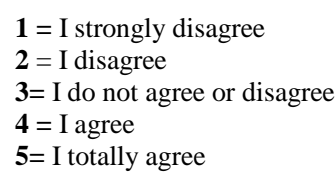

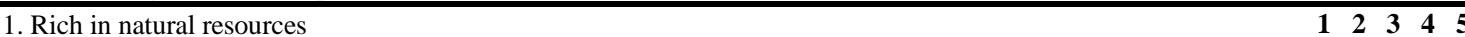

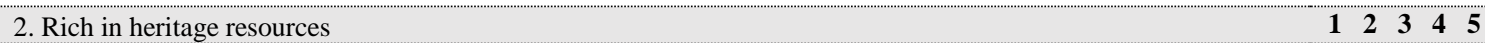

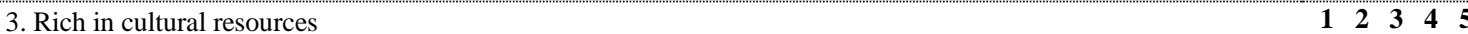

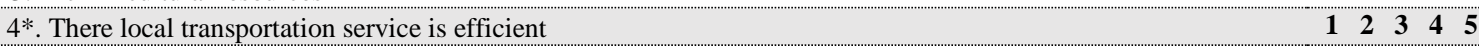

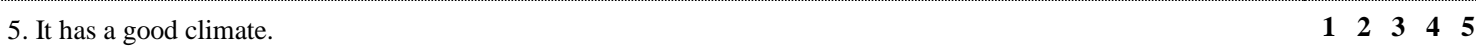

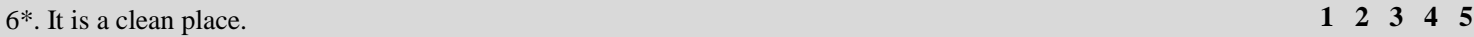

7. Our traditional festivities are unique. $\quad \begin{aligned} & \mathbf{3} \\ & \mathbf{3}\end{aligned} \mathbf{5}$

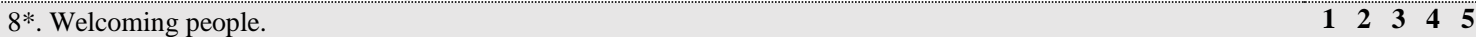

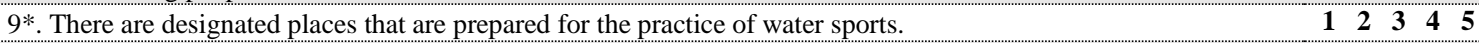

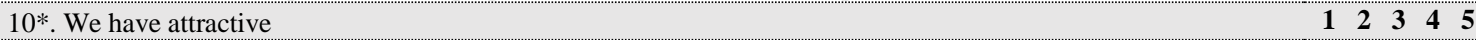

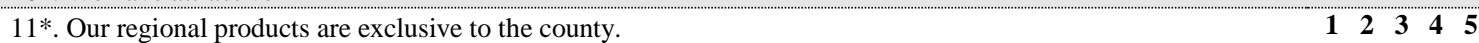

12. It is a good shopping place. $\quad-12345$

13. Diversity of good quality accommodation services $\quad \begin{aligned} & \mathbf{2} \\ & \mathbf{4}\end{aligned}$

14. The touristy sites are well signalized. $\quad 1.2 \quad 3 \quad 4 \quad 5$

15.. Having trendy and different things makes it distinct when compared with the nearest tourism destinations.

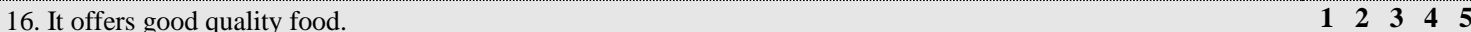

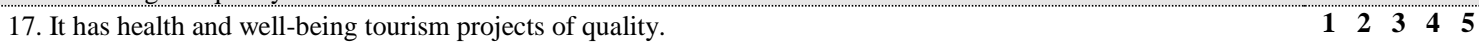

$18^{*}$. Wine, fruits and other agricultural goods are a tourism attraction. $\quad 12345$

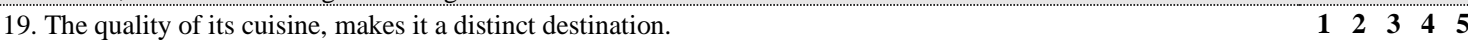

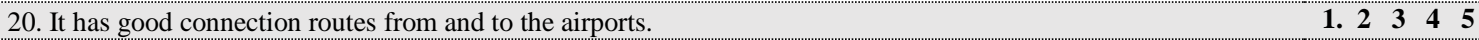

22. It offers a diverse array of entertainment options. $\quad r \begin{array}{llll}\mathbf{3} & \mathbf{4}\end{array}$

23. There are various viewpoints. $\quad \begin{aligned} & \mathbf{1} \\ & \mathbf{3}\end{aligned}$

24. It has the necessary infrastructures to enable the practice of tourism. $\quad \mathbf{2} 3 \mathbf{4} 5$

$25^{*}$. There are databases with the characterization of the county's tourism agents (businesses, artisans, $\quad \begin{aligned} & \mathbf{2} \\ & \mathbf{4}\end{aligned}$ associations, etc.).

Source: Authors

Note: $(*)$ Items deleted after exploratory factor analysis 


\subsection{Procedures}

The data used in this study were collected taking into account ethical issues such as participants' anonymity, data confidentiality, and as well for avoiding biases.

An online version of the questionnaire was built using Google Forms and sent by e-mail to all Portuguese municipalities. The average time of response was 12 minutes. The control of the responses was carried out monthly through the variable 'Municipality', being sent a reminder to the municipalities that had not yet responded, reinforcing the importance of their participation in the study. The questionnaire had the instruction that it should be filled in by representatives of the municipality with responsibilities in tourism. Information on the objectives of the study, completion instructions, and the voluntary and anonymous nature of the participation and the guarantee of data confidentiality were also included in the beginning of the questionnaire.

\section{Data analysis}

All the analyses were completed using the statistical program SPSS and AMOS 22.0 for Windows operative system. Outliers were analysed according to Mahalanobis squared distance (Tabachnick \& Fidell 2007), not having been found values relevant. The normality of the variables was assessed by the coefficients of skewness $(S k)$ and kurtosis $(K u)$, showing that no variable presented values violating normal distribution, $|S k| \leq 1.49(S E=.209)$ and $|K u| \leq 3.16(S E=.416)$.

Exploratory factor analysis was performed using SPSS by Principal Component Analysis (PCA). The PCA assumptions were tested through the sample size (ratio of 5 subjects per item and at least 100 participants; Gorsuch, 1983), the normality and linearity of the variables, factorability of $R$, and sample adequacy (Tabachnick \& Fidell, 2013). Since we expected to obtain correlated factors, we have chosen Direct Oblimin rotation method with Kaiser's normalization.

Confirmatory factorial analysis was performed with AMOS (v. 22.0, SPSS Inc, Chicago, IL; Arbuckle, 2013), estimation method by maximum likelihood (Jöreskog \& Sörbom, 2004). Goodness of fit was analysed by the indexes of NFI (Normed of fit 
index; good fit > .80; Schumacker and Lomax 1996), SRMR (Standardized Root Mean Square Residual; appropriate fit<.08; Brown 2006), CFI (Comparative fit index; good fit > .90; Bentler, 1990), RMSEA (Root Mean Square Error of Approximation; good fit $<.05$; Kline 2011; Schumacker \& Lomax, 2010), and $X^{2} / \mathrm{df}$ (acceptable fit < 5; good fit < 2; Marôco, 2011; Schumacker \& Lomax, 2010). The improvement of model fit was evaluated by the modification indices (MI; Bollen, 1989), and we considered liberating the parameters with higher MI. We followed Arbuckle's proposal (2013), which consists in analyzing the MIs by their statistical significance $(\alpha<0.05)$. Inside each factor, the correlation of the residual variability between variables with MI > 11 was performed (Marôco, 2011).

Reliability was calculated by Cronbach's alpha (Nunally, 1978). Despite reliability coefficients higher than .70 were considered acceptable for convergence and reliability (Hair, Black, Babin \& Anderson, 2009), we've chosen the value of .80 as a good reliability indicator. The composite reliability and the average variance extracted for each factor were evaluated as described in Fornell and Larcker (1981).

\section{Results}

Exploratory factor analysis was initially carried out because the scale items were developed based o literature review (see Table 3 for PCA main results). After the factors' extraction, the factorial solution was analysed by a confirmatory factor analysis. The goodness-of-fit statistics indicated that the structural model fit was acceptable (see Table 4 for fit indices and Figure 1 for the structural model).

\subsection{Exploratory factor analysis}

The requirements for a reliable interpretation of PCA were analysed. Since the questionnaire we used has 25 items, the ratio found was 134 subjects $/ 25$ items $=5.36$ subjects/item, which enables, according to Gorsuch (1983), a reliable use of PCA. The inter-correlation matrix and the identity matrix were different, $X^{2}(136)=779.22, p$ $<.001$ for the Bartlett's test, and the sampling was higher than the required value of .70, Kaiser-Meyer-Olkin $(\mathrm{KMO})=.723$. 
Eight factors emerged according to the eigenvalue criteria over one, explaining $66.90 \%$ of the total variance. This factorial solution was not interpretable, and it is not in accordance to the Scree plot, which discriminates a maximum of 4 factors. Attending to the factorial loadings $(s)$, we found an amount of items with scores lower than .50 (Tabachnick \& Fidell, 2013) and others with similar factorial loadings in more than one factor. Additionally, excluding these items leads to an improvement of the Cronbach's alpha. These situations lead us to the exclusion to the eight items: 8 - 'People are hospitable'; 10 - 'Our regional products are attractive'; 6 - 'It is a clean place'; 9 'There are places prepared for the practice of water sports'; 25 - 'There are databases with the characterization of local tourist agents (companies, artisans, associations, etc.)'; 11 - 'Our regional products are exclusive to the municipality'; 18 - 'Wine, fruit and other agricultural products are a tourist attraction'; and 4 - 'There is an efficient local transportation service'.

With the remaining 17 items three factors emerged as more distinctive both attending the eigenvalues score and the scree plot. These factors explain $49.83 \%$ of the total variance, with the first factor explaining $25.79 \%$, the second factor $13.81 \%$, and the third $10.24 \%$. Factorial loadings (s) are above .38 and the majority are higher than than .50 (Tabachnick \& Fidell, 2013; see Table 3). Factor 1 is composed of seven items related to the variety and quality of tourism enterprises, accommodation, gastronomy, shopping, and tourism information. These were the most valued aspects by the respondents concerning the creation of a tourism product that assures the quality and competitive differentiation of Portuguese destinations. Reason why this factor has been designated 'Services'.

Factor 2 also comprises seven items concerning endogenous resources, climate, traditions and entertainment and was called 'Resources and attractions'. At last, the third factor was named 'Accessibilities and infrastructures', since it is comprised by 3 items concerning to connections and tourism infrastructure.

Table 3

PCA of the Tourism product dimension measure: Factorial loadings of F1, F2, and F3, communalities (h2), eigenvalues, and shared variance of the Pattern matrix

\begin{tabular}{|c|c|c|c|c|}
\hline & $\begin{array}{c}\mathrm{F} 1 \\
\text { Services }\end{array}$ & $\begin{array}{c}\mathrm{F} 2 \\
\text { Resources and } \\
\text { attractions }\end{array}$ & $\begin{array}{c}\text { F3 } \\
\text { Accessibilities } \\
\text { and } \\
\text { infrastrutures }\end{array}$ & $h 2$ \\
\hline 19. It is distinguished by the quality of its gastronomy. & .743 & -.021 & -.101 & .515 \\
\hline 16. It has quality food. & .726 & -.012 & .135 & .595 \\
\hline 17. It has quality tourism enterprises of health and well-being. & .722 & -.174 & -.047 & .475 \\
\hline
\end{tabular}




\begin{tabular}{|c|c|c|c|c|}
\hline 13. It has quality diversity of accommodation. & .654 & .157 & -.084 & .477 \\
\hline 14. The tourist sites are well signposted. & .646 & .040 & .017 & .439 \\
\hline 12. It is a good place to shop. & .641 & -.036 & .071 & .430 \\
\hline $\begin{array}{l}\text { 15. It is distinguished by having things new and different from the } \\
\text { nearest tourist destinations. }\end{array}$ & .495 & .206 & .054 & .358 \\
\hline 2. It is rich in assets. & .066 & .752 & -.033 & .589 \\
\hline 3. It is rich in cultural resources. & .104 & .742 & .066 & .619 \\
\hline 1. It is rich in natural resources. & -.099 & 698 & -.164 & .474 \\
\hline 23. It has a variety of landscape observation points. & -.029 & .652 & -.065 & .412 \\
\hline 7. His traditional festivities are unique. & -.007 & .595 & .114 & .379 \\
\hline 5. It has a good climate. & .020 & .394 & .023 & .163 \\
\hline 22. It has variety of entertainment. & .255 & .387 & .280 & .404 \\
\hline 21. It has good road access. & .017 & -.089 & .896 & .801 \\
\hline 20. It has good accessibility from the airports. & .027 & -.185 & .872 & .771 \\
\hline 24. It has infrastructures for tourism practice. & -.063 & .234 & .713 & .573 \\
\hline Eigenvalues & 4.38 & 2.2834 & 1.74 & \\
\hline$\%$ of explained variance & 25.79 & 13.81 & 10.24 & \\
\hline
\end{tabular}

Source Own source based on the SPSS software output (version 22.0)

\subsection{Confirmatory factor analysis}

CFA was performed in order to test the fit of the factorial solution found by EFA (see fit indices for model 1 in Table 3, no error terms correlated). For model 1, only the $\chi^{2} / \mathrm{df}$ showed an acceptable fit. In model 2 error terms were correlated between the items belonging to the same factor, based on the higher modification indices (see Figure 1). This covariation might indicate non-random measurement errors, which can result from some semantic redundancy between items, sequential positioning in the scale, as well as the specific characteristics of the respondents (Aish \& Jöreskog, 1990). Model 2 showed a good fit for CFI and $\chi^{2} / \mathrm{df}$, an acceptable fit for SRMR and RMSEA (see Table 4, model 2).

Fit statistics of the three-factor model for 'Tourism product' dimension measure

Table 4

\begin{tabular}{ccccccc}
\hline Model & NFI & SRMR & CFI & $\chi^{2} / d f$ & RMSEA & $\begin{array}{l}\text { RMSEA } \\
90 \% \text { CI }\end{array}$ \\
\hline 1 & .659 & .089 & .774 & $2.18^{*}(d f=116)$ & .095 & $.079-.110^{*}$ \\
\hline 2 & .771 & .075 & .904 & $1.52^{*}(d f=113)$ & .063 & $.043-.081^{*}$ \\
\hline
\end{tabular}

Source: Own source based on the AMOS software output (version 22.0)

Note: X2 chi-square, df degrees of freedom, NFI normed fit index, CFI comparative fit index, PNFI parsimony normed fit index, SRMR standardized root mean square residual, RMSEA root mean square error of approximation, CI confidence interval, $* p<.05$

In Figure 1 can be seen the standardized regression weights (ranged from .25 to .88 ) and the squared multiple correlations (ranged from 6 to $77 \%$ ) of model 2. Despite item 21 has the lower regression weight, the communality in EFA is high and we consider this item as an important one in Factor 3, attending its content. 
Cronbach alpha for the global scale are good $(\alpha>.80$; see Table 4$)$, and acceptable for factors 1 and $2(\alpha>$.70). Factor 3 reached a low reliability, which can be due to its small number of items ( 3 items), among other reasons. This score is near .60, alpha's value accepted by DeVellis (2003) and items 21 and 24 have a corrected itemtotal correlation above the .30 reference value suggested by Field (2009).

Figure 1

CFA for 'Tourism product' dimension measure (model 2): standardized regression weights and squared multiple correlations

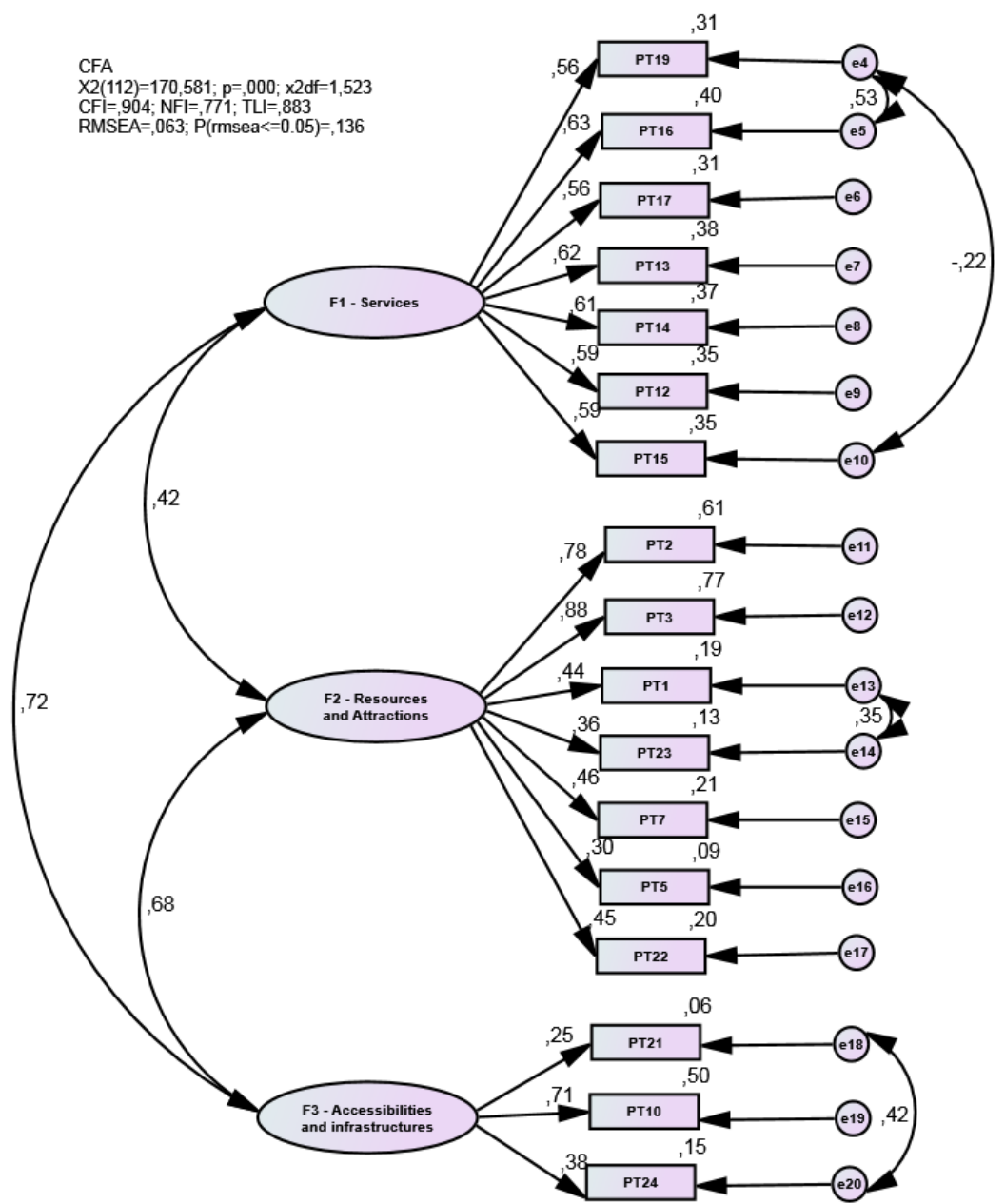

Source: Own source based on the AMOSSPSS software output (version 22.0)

Composite reliability showed good scores only for factors 1 and 2, since higher than .70. Concerning the average variance extracted (AVE), none of the factors exceed the cut-off value of .40 that is indicator of an acceptable convergent validity (Diamantopoulos \& Siguaw, 2000), which points out the need to revise the items 
regarding the issue of convergent validity. Discriminant validity should also be revised, given that, excluding the $\mathrm{R}_{\mathrm{F} 1, \mathrm{~F} 2}^{2}$ score, the AVE corresponding to each factor is not higher than the squared correlations $\left(R^{2}\right)$ between the three factors (Fornell \& Larcker 1981).

Mean score for the Global scale showed a value near the 4th point of the Likert scale. The scores for both factors were similar, receiving the F1 the lower score and the F2 the highest score (Table 5).

Table 5

Composite reliability $(C R)$, average variance extracted $(A V E)$, Cronbach's Alpha $(\alpha)$, means $(M)$, standard-deviations $(S D)$, and intercorrelations among factors $\left(R^{2}\right.$ between brackets) for 'Tourism product' Subscale

\begin{tabular}{|c|c|c|c|c|c|c|c|c|c|c|}
\hline & \multirow{2}{*}{$C R$} & \multirow{2}{*}{$A V E$} & \multirow{2}{*}{$\alpha$} & \multirow{2}{*}{$\min$} & \multirow{2}{*}{ máx } & \multirow{2}{*}{$M$} & \multirow{2}{*}{$S D$} & \multicolumn{3}{|c|}{$R^{2}$} \\
\hline & & & & & & & & $F 1$ & $F 2$ & $F 3$ \\
\hline Global scale & - & - & .822 & 2.94 & 5.00 & 3.91 & 0.43 & & & \\
\hline F1-Services & .792 & .352 & .786 & 1.57 & 5.00 & 3.62 & 0.61 & - & .176 & .518 \\
\hline $\begin{array}{l}\text { F3 - Accessibilities and } \\
\text { infrastructures }\end{array}$ & .442 & .238 & .583 & 2.33 & 5.00 & 4.09 & 0.57 & & & - \\
\hline
\end{tabular}

Source: Own source based on the AMOS software output (version 22.0)

$* p<.001$

\section{Discussion and Implications}

The results highlight three dimensions that should be considered when structuring a tourism product in order to assure its quality. These are: services, resources and attractions, and accessibilities and infrastructures. As referred to previously, the promotion dimension is a fundamental component for the structuring of the tourism product.

Tourism requires activities. The activities most valued by the respondents were gastronomy, shopping, and wellness. These need to be complemented with quality accommodation and tourism information services (Bohlin et al., 2016; Ferdinand \& Williams, 2013; Getz \& Page, 2016; Soares et al., 2015). These aspects were defined as qualifying or emerging assets in the Portuguese tourism strategy, defined by the 'Government' for 2027 (Turismo de Portugal, 2017). In this document the greatest challenges tourism will face, in Portugal, in the next decade are presented. Strategic markets for future investment are also defined, from which stand out Asia Pacific and 
Brazil. The primary motivations for these markets to visit Portugal are precisely: gastronomy, shopping, and wellness.

These tourists also highly appreciate quality accommodation. However, promotion services, as well as tourism information, are essential to make Portugal known as a tourism destination, as well as help tourists take the most out of their visit without wasting unnecessary time. Services are responsible for aggregating in an organized fashion all the activities tourists might, or not, be able to find on their own (Blasco et al., 2014; Bohlin et al., 2016). They also facilitate the combination of different activities that enrich the tourism experience (Booyens \& Rogerson, 2016). They include tourism information services which are a fundamental tool for travel planning and in the divulgation of all the fundamental activities to the tourism activity. These are the ones that make it possible to know which products exist, as well as indicate how to access them.

These results suggest that participants of this study are aware of the challenges proposed by the Government and that they share the same objectives. They also indicate that this can be a strategy to make Portugal a tourism destination different from the destinations of proximity and, therefore, competitive and attractive internationally. This combination of interests and objectives between the public and private sectors, regarding the 'services' is a positive sign in the development of tourism in Portugal. And it can be one of the most important differentiating assets in the organization of quality and competitive tourism.

There is also an association between item 19. 'It is distinguished by the quality of its gastronomy' and item 15. 'It is distinguished by having things new and different from the nearest tourist destinations.' This result suggests that one of the distinguishing assets of tourism attractiveness in Portugal is its gastronomy. This is one of the products that can contribute to increase the competitiveness of this destination in relation to destinations of proximity.

The high ratio of factor 1 'Services' to factor 3 'Accessibilities and infrastructures' reinforces what was said earlier. Without getting the tourists to the destination there is no tourism. Access to activities is key. There are many activities that are quite attractive, but the difficulties associated with travel are so many that they make tourists give up (Gretzel, Hwang \& Fesenmaier, 2012; Pearce \& Schänzel, 2013). Access is key to exploring the attractions. These are the ideas that stand out in factor 3 
('Accessibilities and infrastructures'). It also appears that at the level of connections, rather than road networks, are the good accessibility of airports that contribute most to the quality and competitiveness of destinations. This assertion is supported by the low correlation between items 21. 'It has good road access' and factor 3, meaning that this item contributes little to the explanation of this construct (see Figure 1). In summary, tourism infrastructures and airways are the most important elements in attractiveness of the tourism product at the international level because they allow tourists to reach the destination and increase their stay rate (Brouder \& Ioannides, 2014, Leiper, 1979, 2000, 2004). In other words, it is the infrastructures and attractions that allow carrying out a set of activities that fix the tourists in the territories.

Factor 3 ('Accessibilities and infrastructures') reflects what has been defended by Turismo de Portugal, regarding the goals that tourism has already reached, at national level. The diversity of the offer and the freedom to travel within the destination has been accompanied by the increase of the air accessibilities. These are also the conditions that the Portuguese municipalities defend as central to the development of tourism at the local level, especially in inland tourism. And these are the necessary requirements to stimulate the creation of competitive and quality tourism products, in the opinion of the Guardianship and the local agents.

Finally, we need to address the content reflected by factor 2 ('Resources and attractions'). The tourism experience depends on the type and combination of activities experienced. As well as, the selected activities are adequate to the profile, tastes, motivations and age of the tourists, among others (Badulescu, et al., 2016). The differentiation of products is an added value in the experience of unforgettable tourism experiences, because it is different from everything that people have ever lived. The richness and diversity of natural and cultural resources ensure the attractiveness of tourists as long as they are transformed into competitive tourism products (Bernabé \& Hernández, 2016). Hence, it is extremely important to reflect local traditions on local traditions and customs in entertainment activities. Innovation in tourism products from endogenous resources adds value and competitive capacity to destinations (Bohlin et al., 2016; Sanz-Ibáñez \& Clavé, 2016). It is also this strategy that emphasizes the differentiating characteristics of the territories and contributes to increase their attractiveness (Badulescu et al., 2016; Booyens \& Rogerson, 2015, 2016; De Noni et al., 2014; Rovira, 2016). It is also worth mentioning that 'having a good climate' (item 5) 
and 'variety of landscape observation points' (item 23) were also considered by the respondents as attractive assets, around which the Portuguese tourism products should be structured. However, attention is drawn to the fact that item 5. 'It has a good climate' is what least contributes to explain Factor 2 ('Resources and attractions').

The correlation between factors 2 ('Resources and attractions') and 3 ('Accessibilities and infrastructures') has been explained previously. It's important to have resources, but even more important is for these to inspire the design of tourism products able to translate the culture and traditions. It's fundamental to have infrastructure that supports and stimulates product innovation, promotion and commercialization. It is equally fundamental to get tourists to destinations.

\section{Conclusion}

The premises that facilitate the attractiveness and competitiveness of tourism products, defended by the authors of the specialty identified in these results are verified (Bernabé \& Hernández, 2016; Bohlin et al., 2016; Ferdinand \& Williams, 2013; Getz \& Page, 2016; Rovira, 2016; Timothy et al., 2016; Wieckowski \& Cerić, 2013). Cultural and natural wealth, variety of attractions and entertainment associated with infrastructure and connections are the factors that Portuguese counties value the most so that products differentiate from one another and maintain the level of quality expected by tourists. Once again, the coherence between 'Government' and local entities is observed, when it comes to development of tourism products in Portugal, because the results analysed here show that local leaders are aware of the tourism potential of the country. It also shows that these actors value what converges the most to: (i) differentiation of tourism destination and its competitiveness; (ii) association between product quality and the authenticity of the tourism experience; (iii) the necessity to invest in infrastructure; and (iv) the consolidation of air ways and airports expansion to facilitate the arrival of tourists to destinations. These points are expressed in the Governments' strategy for tourism in Portugal until 2027 (Turismo de Portugal, 2017) and are part of the speech of local public decision makers, such as shown by the results.

Attention is drawn to some frailties of this measuring instrument, which leads us, in future studies, to rethink the contribution of each item to the studied instrument, following the recommendations of DeVellis (2012) e Netemeyer et al. (2003). We're 
referring to the internal consistency coefficient of factor 3 ('Accessibilities and infrastructures') and to the value of intercorrelations of items 5 ('It has a good climate') and 21 ('It has good road access'). These results suggest the need for further studies that allow the improvement of some adjustment indexes obtained in the confirmatory factorial analysis. However, this theme's importance and the fact that the items constituting the three factors represent what is defended by the Portuguese Government as being the Portuguese tourism strategy for the next decade, when it comes to developing products, led to further reflection on this data, not excluding any of the items that the round factor solution retained. The association verified between items 19 ('It is distinguished by the quality of its gastronomy') and 16 ('It has quality food') suggests some semantical redundancy between these two questions, indicating that this instrument may improve with the suppression of one of them. Future studies based on the application of the subscale to other contexts may contribute to a better explanation of this result.

For the above reasons, the longitudinal application of the proposed instrument is suggested, as well as in other international contexts to make comparative analyses and to establish temporal evolutions or similarities and differences between countries. In addition, it is essential to deepen the knowledge in this area, imposing the continuation of the study of this theme and the other dimensions of quality that make up this scale, namely: development, economics, human resources and marketing.

\section{Acknowledgements}

We are grateful for the participation of the Portuguese public decision-makers at the local level that contributed with their experience and knowledge to the present research.

\section{References}

Aish, A., \& Jöreskog, K. (1990). A panel model for political efficacy and responsiveness: An application of LISREL 7 with weighted least squares. Quality and Quantity, 19, 716-723.

Arbuckle, J. L. (2013). Amos 22 user's guide. Chicago, IL: SPSS.

Badulescu, D., Hoffman, I., Badulescu, A, \& Simut, R. (2016). Local authorities' involvement in fostering Hungarian-Romanian cross-border cooperation in tourism. Lex 
Localis, Journal of Local Self-Government, 14(3), 337-358. doi:10.4335/14.3.337358(2016).

Bagozzi, R., \& Yi, Y. (1988). On the evaluation of structural equation models. Journal of the Academy of Marketing Science, 16 (1), 74-94.

Bentler, P. (1990). Quantitative methods in psychology: Comparative fit indexes in structural models. Psychological Bulletin, 107, 238-246.

Bernabé, C., \& Hernández, M. (2016). Turismo en Albarracín y Comarca: Acción pública local y dinâmica reciente en clave de desarrollo turístico sostenible. Anales de Geografía de la Universidad Complutense, 36(1), 173-194. doi:10.5209/rev_AGUC.2016.v36.n1.52718.

Blasco, D., Guia, J., \& Prats, L. (2014). Tourism destination zoning in mountain regions: A consumer-based approach. Tourism Geographies, 16(3), 512-528. doi:10.1080/14616688.2013.851267.

Bohlin, M., Brandt, D., \& Elbe, J. (2016). Tourism as a vehicle for regional development in peripheral areas: Myth or reality? A longitudinal case study of Swedish regions. European Planning Studies, 24(10), 1788-1805. doi: 10.1080/09654313.2016.1194807.

Bollen, K. A. (1989). Structural equations with latent variables. New York: Wiley. Booyens, I. (2016). Global-local trajectories for regional competitiveness: Tourism innovation in the Western Cape. Local Economy, 31(1-2), 142-157. doi: $10.1177 / 0269094215618598$.

Booyens, I., \& Rogerson, C. M. (2015). Creative tourism in Cape Town: An innovation perspective. Urban Forum, 26, 405-424. doi: 10.1007/s12132-015-9251-y.

Booyens, I., \& Rogerson, C. M. (2016). Unpacking the geography of tourism innovation in Western Cape Province, South Africa. Bulletin of Geography, Socio-economic Series, 31, 19-36. doi: 10.1515/bog-2016-0002.

Brouder, P., Ioannides, D. (2014). Urban tourism and evolutionary economic geography: Complexity and co-evolution in contested spaces. Urban Forum, 25, 419430. doi: 10.1007/s12132-014-9239-z.

Brown, T. A. (2015). Confirmatory factor analysis for applied research ( $2^{\text {nd }}$ Ed.). NewYork: Guilford Press.

Cohen, J. (1988). Statistical power analysis for the behavioural sciences $\left(2^{\text {nd }}\right.$ Ed.). Hillsdale, NJ: Erlbaum.

Comissão Europeia (2000). Para um turismo urbano de qualidade: Gestão integrada da qualidade (GIQ) dos destinos turísticos urbanos. Luxemburgo, Serviço das Publicações Oficiais das Comunidades Europeias. 
Comissão Europeia (2003). A manual for evaluating the quality performance of tourist destinations and services. Luxembourg, Office for Official Publications of the European Communities.

Comissão Europeia (2013). Caixa de ferramentas do sistema europeu de indicadores de turismo para destinos sustentáveis. Luxemburgo, Serviço de Publicações da União Europeia.

Comissão Europeia (2016). The European tourism indicator system: ETIS toolkit for sustainable destination management. Available at http://ec.europa.eu/growth/sectors/tourism/offer/sustainable/indicators/index_en.htm.

De Noni, I., Orsi, L., \& Zanderighi, L. (2014). Attributes of Milan influencing city brand attractiveness. Journal of Destination Marketing \& Management, 3, 218-226. doi: 10.1016/j.jdmm.2014.06.001

DeVellis, R. (2003). Scale development: Theory and applications ( $2^{\text {nd }}$ Ed.). Thousand Oaks, CA: Sage.

Diamantopoulos, A., \& Siguaw, J. A. (2000). Introducing to Lisrel: a guide for the uninitiated. London: Sage.

Ferdinand, N., \& Williams, N. (2013). International festivals as experience production systems. Tourism Management, 34, 202-210. doi:10.1016/j.tourman.2012.05.001.

Field, A. (2005). Discovering statistics using SPSS ( $3^{\text {rd }}$ Ed.). London: Sage.

Fornell, C., \& Larcker, D. F. (1981). Evaluating structural equation models with unobservable variables and measurement error. Journal of Marketing Research, 18(1), 39-50.

Getz, D., \& Page, S. (2016). Progress and prospects for event tourism research. Tourism Management, 52, 593-631. doi: 10.1016/j.tourman.2015.03.007.

Gorsuch, R. (1983). Factor analysis. Hillsdale, NJ: Lawrence Erlbaum.

Gretzel, U., Hwang, Y. H., \& Fesenmaier, D. R. (2012). Informing destination recommender systems design and evaluation through quantitative research. International Journal of Culture, Tourism and Hospitality Research, 6(4), 297-315.

Hair, J. F., Black, W.C., Babin, B. J., \& Anderson, R.E. (2009). Multivariate data analysis $\left(7^{\text {th }}\right.$ Ed.). New Jersey: Prentice Hall.

Jöreskog, K. G., \& Sörbom, D. (2004). LISREL 8.7 for Windows [Computer Software]. Lincolnwood, IL: Scientific Software International, Inc.

Királová, A. (2015). Sustainable Tourism Marketing Strategy: Competitive Advantage of Destination, In N. Ray (Ed.) Emerging Innovative Marketing Strategies in the Tourism Industry (pp. 54-81), Hershey, IGI Global: A volume in the Advances in Hospitality, Tourism, and the Services Industry (AHTSI) Book Series. 
Királ'ová, A.(2016). Creativity as a tool of tourism development. In A. Királ’ová (Ed.) Driving Tourism through Creative Destinations and Activities pp. 67-93, Hershey, IGI Global: A volume in the Advances in Hospitality, Tourism, and the Services Industry (AHTSI) Book Series.

Kline, R. (2011). Principles and practice of structural equation modeling ( $3^{\text {rd }}$ Ed.). New York: The Guilford Press.

Leiper, N. (1979). The framework of tourism: Towards definitions of tourism, tourists and the tourism industry. Annals of Tourism Research, 6, 390-407.

Leiper, N. (2000). Are destinations 'the heart of tourism'? The advantages of an alternative description. Current Issues in Tourism, 3(4), 364-368.

Leiper, N. (2004). Tourism management ( $3^{\text {rd }}$ Ed.). Frenchs Forest: Pearson Education Australia.

Marôco, J. (2011). Análise de equações estruturais: Fundamentos teóricos, software \& aplicações. Pêro Pinheiro: Report Number.

Mira, M. R., Breda, Z., Moura, A., \& Cabral, M. (2017). O papel das DMO na gestão dos destinos turísticos: Abordagem conceptual (1999-2014). Observatório de Inovação do Turismo - Revista Acadêmica, 11(1), 53-70.

Mira, M. R., Mónico, L., \& Moura, A. (2017). Qualidade dos recursos humanos em turismo: A opinião dos decisores públicos portugueses. Revista Psicologia: Organizações e Trabalho, 17(4), 1-10. doi: 10.17652/rpot/2017.4.13746.

Mira, M. R., Moura, A., \& Breda, Z. (2016). Destination competitiveness and competitiveness indicators: Illustration of the Portuguese reality. TÉKHNE - Review of Applied Management Studies, 14, 90-103. doi.org/10.1016/j.tekhne.2016.06.002.

Mira, M. R.; Mónico, L.; Moura, A. \& Breda, Z. (2017). Qualidade do desenvolvimento turístico na perspetiva dos decisores públicos locais Portugueses: Uma proposta de medida. Revista Turismo \& Desenvolvimento, 27/28(1), 1675 - 1687.

Netemeyer, R. G., Bearden, W. O., \& Sharma, S. (2003). Scale development in the social sciences: Issues and applications ( $1^{\text {st }}$ Ed.). Palo Alto CA: Sage.

Nilsson, J. H., Eskilsson, L., \& Ek, R. (2010). Creating cross-border destinations: Interreg programmes and regionalisation in the Baltic Sea Area. Scandinavian Journal of Hospitality and Tourism, 10(2), 153-172. doi: 10.1080/15022250903561978.

Nunnally, J. C. (1978). Psychometric theory. New York, McGraw-Hill.

Pearce, D., \& Schänzel, H. (2013). Destination management: The tourists' perspective. Journal of Destination Marketing \& Management, 2, 137-145. doi: /10.1016/j.jdmm.2013.06.001. 
Rovira, N. (2016). ¿Ciudades en el mapa o en la guía turística? Venta de la ciudad y sentido del lugar. Revista CIDOB d'Afers Internacionals, 113, 89-105.

Sanz-Ibáñez, C., \& Clavé, S. (2016). Strategic coupling evolution and destination upgrading. Annals of Tourism Research, 56, 1-15. doi: 10.1016/j.annals.2015.10.010.

Sarasa, J. (2015). Mito y estrategias para un destino romántico: La ciudad de Teruel. Cuadernos de Turismo, 36, 39-54.

Schumacker, R. E., \& Lomax, R. G. (2010). A beginner's guide to structural equation modeling ( $3^{\text {rd }}$ Ed.). Mahwah, N.J.: Lawrence Erlbaum Associates.

Soares, J., Baidal, J., \& Gândar, J. (2015). La evolución de destinos turísticos litorales consolidados: Análisis comparado de balneario Camboriú (Brasil) y Benidorm (España). Anales de Geografia, 35(2), 143-166. doi.org/10.5209/rev_AGUC.2015.v35.n2.50118.

Stylidis, D., Sit, J., \& Biran, A. (2016). An exploratory study of residents' perception of place image: The case of Kavala. Journal of Travel Research, 55(5), 659-674. doi: $10.1177 / 0047287514563163$.

Tabachnick, B. G., \& Fidell, L. S. (2013). Using multivariate statistics (6 ${ }^{\text {th }}$ Ed.) New Jersey: Pearson Education.

Timothy, D., Saarinen, J., \& Viken, A. (2016). Editorial: Tourism issues and international borders in the Nordic Region. Scandinavian Journal of Hospitality and Tourism, 16(1), 1-13, doi: 10.1080/15022250.2016.1244504.

Turismo de Portugal (2017). Estratégia de turismo 2017: Liderar o turismo do futuro. Available at: http://estrategia.turismodeportugal.pt/lista-documentos.

UNWTO (2007). A practical guide to tourism destination management. Madrid: World Tourism Organization.

UNWTO (2010). Survey on destination governance: Evaluation report. Madrid: World Tourism Organization.

UNWTO (2012). Tourism, success, stories and rising stars. World Tourism Conference Proccedings, Kota Kinabalu, Sabah, Malaysia, 4-6 October 2010. Madrid: World Tourism Organization.

Volgger, M., \& Pechlaner, H. (2015). Governing networks in tourism: What have we achieved, what is still to be done and learned?. Tourism Review, 70(4), 298-312. doi: 10.1108/TR-04-2015-0013.

Weidenfeld, A. (2013). Tourism and cross border regional innovation systems. Annals of Tourism Research, 42, 191-213. 
Więckowski, M., \& Cerić, D. (2016). Evolving tourism on the Baltic Sea coast: Perspectives on change in the Polish maritime borderland. Scandinavian Journal of Hospitality and Tourism, 16(1), 98-111. doi: 10.1080/15022250.2016.1244598

\section{Maria do Rosário Campos Mira}

She has a Specialist Professor degree in Tourism at the Higher School of Education, Polytechnic Institute of Coimbra, Rua D. João III, Solum, 3030-329 Coimbra, Portugal mrmira@esec.pt

Her research interests relate to quality, human resources and internationalization of tourism destinations.

\section{Andreia Filipa Antunes Moura}

She has a Ph.D. in Tourism and is Invited Adjunct Professor at the Higher School of Education, Polytechnic Institute of Coimbra, Rua D. João III - Solum, 3030-329 Coimbra, Portugal

andreiamoura@esec.pt

Her research interests relate to accessible and social tourism; tourism planning and destination competitiveness, and human capital in tourism.

\section{Lisete dos Santos Mendes Mónico}

She has a Ph.D. in Social Psychology, European Diploma of Advanced Studies in Social Psychology, and Assistant Professor at the University of Coimbra, Rua Colégio Novo, 3000-115 Coimbra, Portugal

lisete.monico@fpce.uc.pt

She dedicates her professional activity to research in the field of Social Sciences and Methods of research. 